\title{
Horizontal and vertical distribution of cirripede cyprid larvae in an upwelling system off the Portuguese coast
}

\author{
Antonina dos Santos ${ }^{1, *}$, A. Miguel P. Santos ${ }^{1}$, David V. P. Conway ${ }^{2}$ \\ ${ }^{1}$ Instituto Nacional de Investigação Agrária e das Pescas — IPIMAR, Av. Brasília, s/n, 1449-006 Lisbon, Portugal \\ ${ }^{2}$ Marine Biological Association of the United Kingdom, The Laboratory, Citadel Hill, Plymouth PL1 2PB, UK
}

\begin{abstract}
The distribution of cirripede cyprids in relation to associated oceanographic conditions was obtained from a grid survey and intensive vertical sampling at a fixed station located $21 \mathrm{~km}$ off the northwest Portuguese coast in May 2002. Analysis of cyprid length composition allowed separation of 3 species groups. Chthamalus montagui, Pollicipes pollicipes and Balanus perforatus were largely restricted to the neuston layer and showed only low-amplitude vertical migration. Most $C$. stellatus cyprids only appeared in the upper $20 \mathrm{~m}$ at night, a migration which did not appear to be affected by physical conditions in the water column, but some differences in the vertical migration pattern between days were probably related to varying light penetration. $C$. montagui is the most abundant adult species found along the Portuguese coast, but $C$. stellatus cyprids, at densities of up to 8.7 ind. $\mathrm{m}^{-3}$, were the most common sampled in all depth strata at the fixed station. Cyprid horizontal distribution was mainly restricted to an offshore band along the inner shelf, where highest densities were 11 to 15 ind. $\mathrm{m}^{-3}$. This distribution pattern was considered to result from upwellingfavourable wind conditions, creating fronts along the shelf in which the cyprids become concentrated. Cyprid vertical migration, in association with current vertical shear and onshore movement of fronts during upwelling-relaxation periods, may be the mechanisms returning cyprids to the coast to settle. The regularity of these events in the region falls within the period of cyprid viability.
\end{abstract}

KEY WORDS: Cirripede cyprids - Distribution - Chthamalus stellatus - Vertical migration · Portuguese shelf

\section{INTRODUCTION}

Rocky coast cirripedes are one of the most important suppliers of crustacean larvae to coastal systems, and understanding the interactions involved in their recruitment is important in coastal ecosystem management and conservation. There have been many studies on the biology of cirripede larvae (e.g. Sousa et al. 2000, Jenkins et al. 2001, Noda 2004), most over the cyprid settlement phase. Studies on the pre-settlement cyprid phase have generally been restricted to sampling in very shallow coastal waters and often at only one depth. This has provided only limited information on interspecific differences in vertical distribution, but there is evidence that cirripede larvae species can maintain their depth distribution even in shallow frontal conditions (Pineda 1999) and that at least some species perform diel vertical migrations (Garland \& Zimmer 2002, Rawlinson et al. 2005).

As part of the dispersal process, many cyprids can be found a considerable distance offshore (Le Fèvre \& Bourget 1991), but few studies have been carried out on the distribution, behaviour, dispersal mechanisms, and thus potential survival of this part of the population, to compare with observations from shallower sites. Previous research has suggested that distribution of cyprids over shelf areas and their recruitment potential are strongly influenced by ocean currents, upwelling events and relaxation (downwelling) periods (Noda 2004, Broitman et al. 2005), with vertical migration also having a role (Alexander \& Roughgarden 1996). 
Some studies on the recruitment of cirripedes on Portuguese shores have been carried out (e.g. Range \& Paula 2001), but none on the distribution, horizontal and vertical, of the cyprid stages in shelf waters. The commonest cirripede recorded along the Portuguese coast is Chthamalus montagui Southward, 1976, C. stellatus (Poli, 1791) being less abundant, though co-occurring (Sousa et al. 2000, Range \& Paula 2001, Boaventura et al. 2002).

The objective of the present study was to describe the 3-dimensional distribution and any diel vertical migration behaviour of cyprids, particularly Chthamalus spp., on the northern Portuguese shelf, in relation to shelf oceanography, towards a better understanding of offshore dispersal and coastal recruitment mechanisms for the region.

\section{MATERIALS AND METHODS}

Fieldwork. Sampling was carried out during a research cruise aboard RV 'Noruega' (ProRecruit'200202050502) from 9 to 22 May 2002 (Santos 2002), on the Portuguese shelf (Fig. 1).

At the beginning of the cruise, a mooring with 3 current meters (Aanderaa RCM 9) and 2 high-accuracy conductivity, temperature and pressure recorders (CTDs, Sea-Bird Electronics, MicroCats) was deployed on the inner shelf at $40^{\circ} 45.9^{\prime} \mathrm{N}, 08^{\circ} 59.0^{\prime} \mathrm{W}$, approximately $21 \mathrm{~km}$ offshore (Fig. 1). It was positioned at a bottom depth of $60 \mathrm{~m}$, in an area adjacent to the Aveiro coastal lagoon, where cirripede cyprids were expected to be abundant. An initial grid of CTD stations, composed of 4 transects perpendicular to the coast (Fig. 1), was carried out from 11 to 14 May 2002, to obtain, in conjunction with the current meter measurements, a quasi-synoptic view of the mesoscale circulation patterns. Temperature, salinity and chlorophyll a ( $\mathrm{chl}$ a) concentration were measured at each station with a CTD SBE 9p+Seapoint fluoro-meter (S/N 19860-0530), in its first use after factory calibration, with a sampling rate set to 12 or 24 scans s $\mathrm{s}^{-1}$ and a lowering rate of approximately $1 \mathrm{~m} \mathrm{~s}^{-1}$.

The same grid was repeated on 15 to 17 May 2002, but, in addition to CTD sampling at each station, depth-integrated plankton samples to obtain cyprid horizontal distribution data were collected at the inner shelf stations (Fig. 1). Sampling was done using a WP-2 (Working Party No. 2; UNESCO 1968) plankton net of $180 \mu \mathrm{m}$ mesh, fitted with a calibrated flowmeter, towed obliquely between the surface and $10 \mathrm{~m}$ above the bottom.

Environmental sampling was carried out round the mooring position for $69 \mathrm{~h}$, from 18 to 21 May 2002, to describe short time-scale variability and provide a detailed resolution of the vertical structuring of the cyprid population. Temperature, salinity and chl a concentration were measured every hour with the CTD, and depth-stratified zooplankton samples were collected every $2 \mathrm{~h}$ using a Pro-LHPR system, a commercially updated version of the Longhurst Hardy Plankton Recorder (Williams et al. 1983). The Pro-LHPR was fitted with a $280 \mu \mathrm{m}$ mesh net and was towed at 3 to

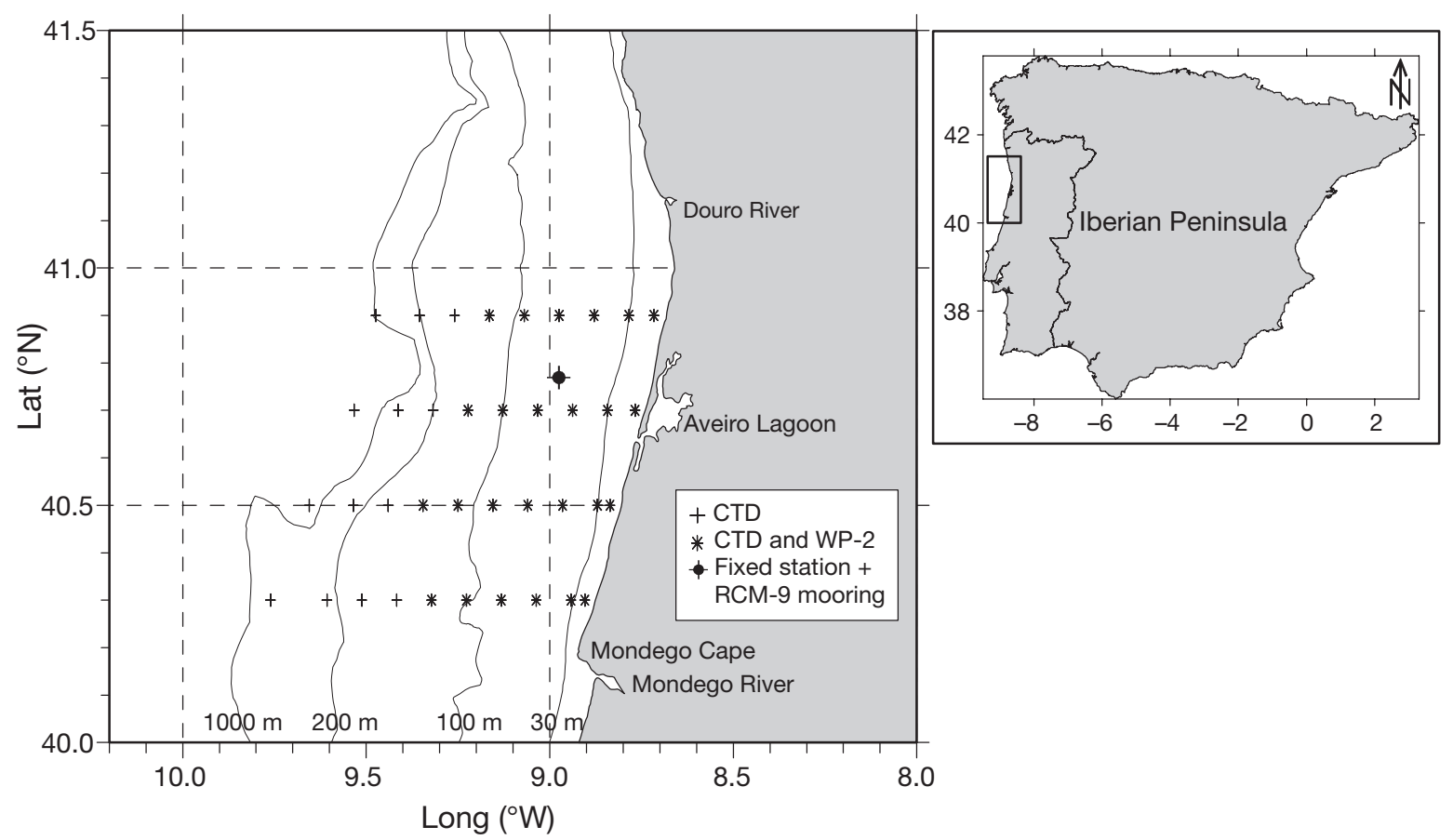

Fig. 1. Location of cruise stations and details of sampling done at each station, 9 to 22 May 2002 
4 knots, sampling on oblique hauls from the surface to $10 \mathrm{~m}$ above the bottom. This system collects zooplankton between 2 rolls of $280 \mu \mathrm{m}$ filtering gauze. The gauze is advanced at specified time intervals inside a cod-end box to give, for each haul, a series of consecutive samples over the water column. The total sampling time for each haul was approximately $30 \mathrm{~min}$. Samples were collected at approximately $5 \mathrm{~m}$ depth intervals in the first $25 \mathrm{~m}$ and at $10 \mathrm{~m}$ depth intervals down to near bottom. Flow rate was monitored by a flowmeter mounted in the mouth aperture, and each sample represented approximately $25 \mathrm{~m}^{3}$ of water filtered. A high-speed net was used, thus avoidance by cyprids is not considered to be a problem.

The Pro-LHPR does not adequately sample the very surface layer, so neuston net samples were also collected every $2 \mathrm{~h}$ at the fixed station. The net had a single rectangular mouth opening of $0.2 \times 1.0 \mathrm{~m}$, a net of $335 \mu \mathrm{m}$ mesh and a flowmeter mounted in the mouth aperture. It was towed horizontally for $3 \mathrm{~min}$ at a ship speed of $\sim 1.5$ knots, sampling the surface $20 \mathrm{~cm}$.

Sample processing. All zooplankton samples were preserved in $4 \%$ borax-buffered formaldehyde, prepared using seawater. Samples were subsequently sorted for cirripede cyprid stages, which were counted and measured. Samples containing $>200$ cyprids were sub-sampled using a stempel pipette. Using flow information, count data were standardised to individuals $\mathrm{m}^{-3}$. Cyprid measurements were made under a binocular microscope (Leica M7.5) and were taken as the carapace length (CL), the distance from the anterior to posterior margin of the carapace. A total of 6222 cyprids were measured. Cyprids, particularly those of Chthamalus montagui and C. stellatus, were identified based on their carapace lengths, following the methods proposed by O'Riordan et al. (1999). They were also separated into the same $25 \mu \mathrm{m}$ class intervals. Length-frequency (total number in each length class divided by the total numbers in all classes) histograms were produced using the class intervals.

Statistical analysis. A Kolmogorov-Smirnov test was used to compare cyprid length classes from the depthstratified night and day samples taken with the neuston and Pro-LHPR nets, and a correlation analysis was carried out on selected cyprid length classes to support the species separation conclusions presented by Power et al. (1999). For comparison of vertical distribution between night and day, weighted mean depth (WMD) values were calculated using the formula given by Pearre (2003). An autocorrelation analysis of the Chthamalus stellatus size class data, and their transformation using the moving averages, normalised per cubic metre of water sampled, was made using the R program (R Development Core Team 2005) to test if the vertical distributions observed had a periodicity that was statistically significant. Additionally, the local diffuse light attenuation coefficient for the surface layer was calculated according to the formula given by Fiksen \& Giske (1995), using the chl a data, to test if cyprids responded to changes in light levels in their vertical distribution behaviour.

\section{RESULTS}

\section{Oceanographic conditions during the cruise}

In the weeks preceding the cruise, northerly winds prevailed, leading to coastal upwelling conditions (Santos et al. 2006). The main response of the surface layer to these conditions was the offshore displacement of the low-saline buoyant plume, the Western Iberian Buoyant Plume (see Peliz et al. 2002), and its mixing with the 'background' shelf and slope waters. This surface layer, with salinities $<35.8$, was present over the entire shelf and slope. A reversal of the wind direction occurred just before the 15 to 17 May WP-2 plankton sampling grid, creating convergence conditions in the surface layers. This had little effect on the hydrography, but led to the development of a poleward current, with values of $\sim 0.05 \mathrm{~m} \mathrm{~s}^{-1}$ over the mid- and inner shelf. At the end of the first day of sampling at the fixed station (18 May), the wind changed again, to northerlies (Fig. 2), and an equatorward upwelling jet ( 0.10 to $0.15 \mathrm{~m} \mathrm{~s}^{-1}$ ) developed over the shelf.

From the hourly CTD readings at the $69 \mathrm{~h}$ fixed station, one of the main characteristics in the vertical distribution of the hydrological fields was the arrival of a lens of less saline water at the surface from 12:00 h on

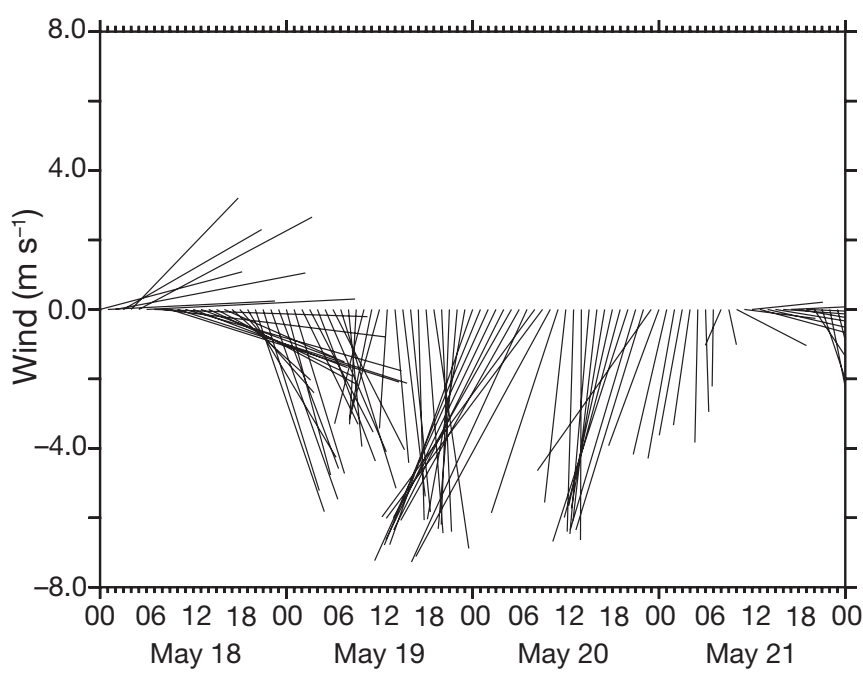

Fig. 2. Wind direction and intensity $\left(\mathrm{m} \mathrm{s}^{-1}\right)$ measured at Cabo Carvoeiro $\left(39^{\circ} 36.0^{\prime} \mathrm{N}, 09^{\circ} 40.0^{\prime} \mathrm{W}\right)$ by the Portuguese Meteorological Institute during 18 to 21 May 2002 

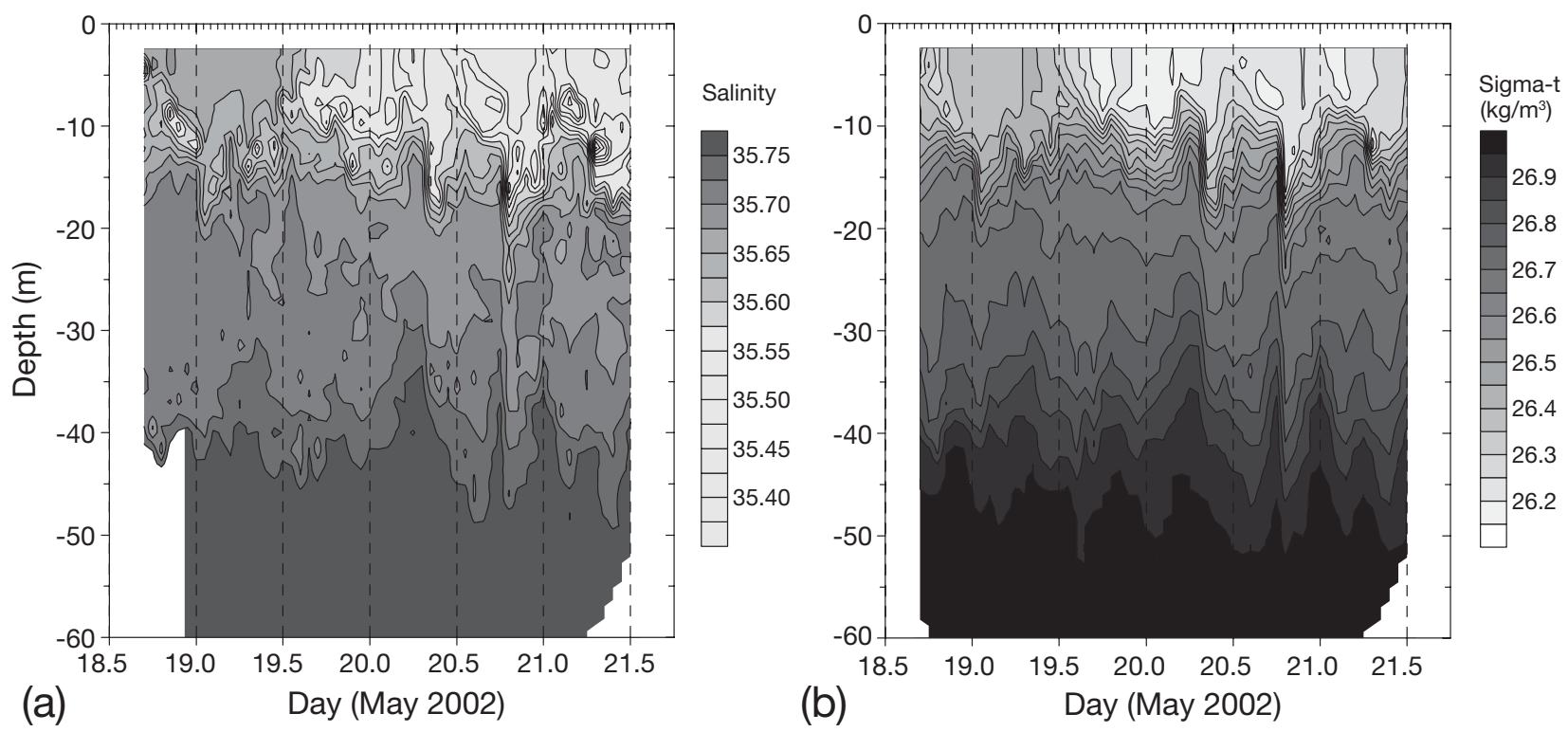

Fig. 3. Sequence of current, temperature and depth measurements of: (a) salinity and (b) density $\left(\sigma_{t}\right)$ during sampling at the $69 \mathrm{~h}$ fixed station, 18 to 20 May 2002. $X$-axis shows sampling date

the second day (Fig. 3a), related to the change in wind and current direction. By the end of sampling, this lens occupied the upper 15 to $20 \mathrm{~m}$ of the surface layer. Considering the wind and current direction, it is probable that it was advected from the northern coast. A second sub-surface salinity minimum was located between 15 and $35 \mathrm{~m}$ depth between 2 pycnoclines (Fig. 3b). A thermocline was also present between 10 and $20 \mathrm{~m}$.

\section{Horizontal distribution of cirripede cyprids}

From the WP-2 net grid sampling, cyprids (all species combined) displayed a pronounced meridional distribution between the 30 and $100 \mathrm{~m}$ contours on the inner shelf (Fig. 4). At the inshore stations they were in very low numbers ( 0.01 to 0.70 ind. $\mathrm{m}^{-3}$ ), with positive stations situated in a band between $2.3 \mathrm{~km}$ from the coast in the most northern transect of the grid to $31 \mathrm{~km}$ from the coast in the second most southern transect. Cyprids were not present further than $40 \mathrm{~km}$ from the coast, and highest numbers (11 to 15 ind. $\mathrm{m}^{-3}$ ) were sampled in the 2 southern transects. However, a 1-way ANOVA test showed no significant differences in abundance between the north and south stations. The same test proved statistically significant differences between inshore and outer shelf areas $(R=0.506, p<$ 0.001), confirming the cross-shore distribution, with cyprids being mainly in the inshore part of the shelf. The $69 \mathrm{~h}$ station was located inside the outer limit of the distribution band.

\section{Length distribution and species of cyprids from neuston and Pro-LHPR sampling}

Length-frequency distribution of all cyprids, from the neuston and Pro-LHPR samples combined, gave a CL range from 376 to $1225 \mu \mathrm{m}$, with very low numbers at the outer limits (Fig. 5). Three discrete modal size

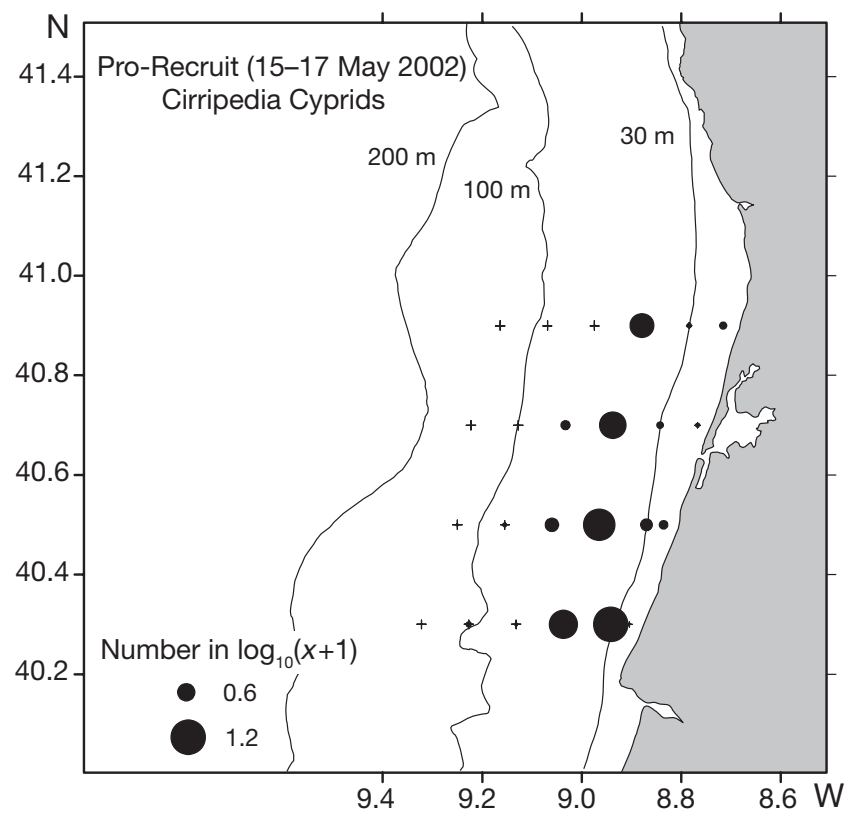

Fig. 4. Horizontal distribution of total cyprids $[\log (x+1), x$ in ind. $\mathrm{m}^{-3}$ ] taken with the WP-2 net during the grid survey, 15 to 17 May 2002 (+: sampling positions) 


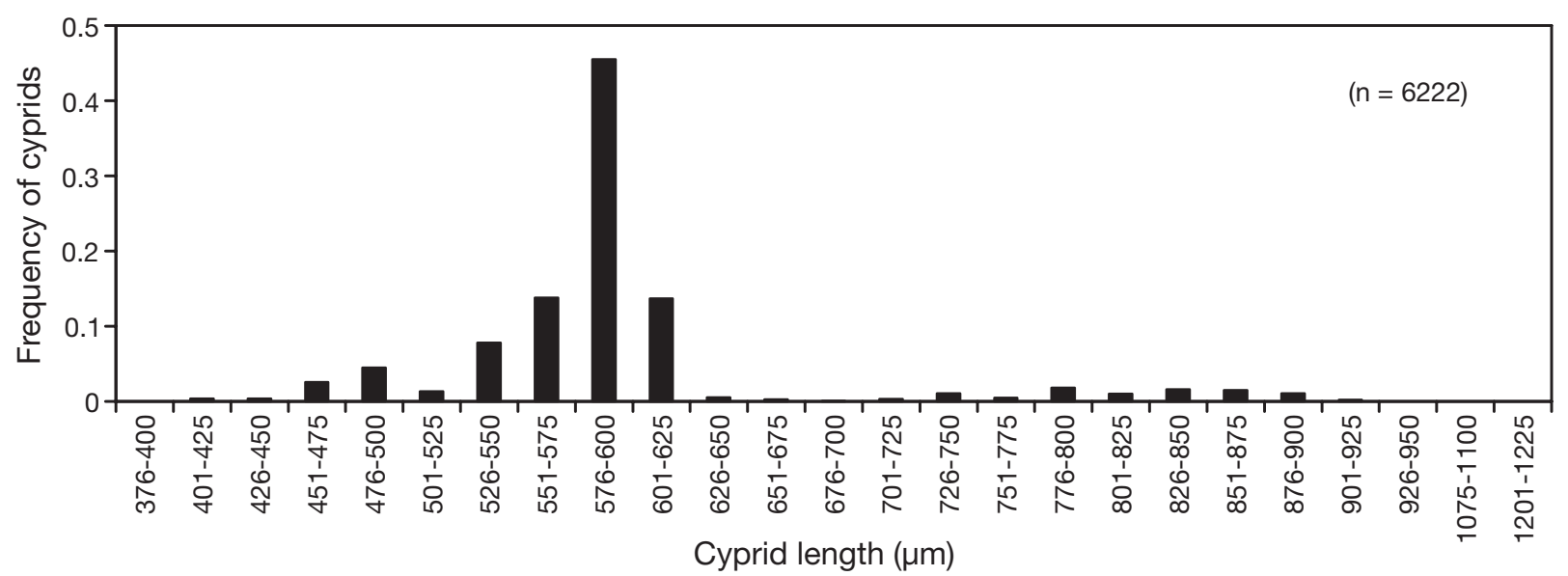

Fig. 5. Size frequency of total cyprids collected in the Neuston and LHPR nets at the $69 \mathrm{~h}$ station. Some values are too small to appear on the diagram

groups could be distinguished, which related to the lengths of cirripede species known to occur in the area. The first at 401 to $525 \mu \mathrm{m}$ would correspond to a mixture of cyprids of Pollicipes pollicipes, which have a range 389 to $475 \mu \mathrm{m}$ (Kugele \& Yule 1996, O'Riordan et al. 2001) and Chthamalus montagui, 350 to $525 \mu \mathrm{m}$ (O'Riordan et al. 2001). The second modal group, 526 to $625 \mu \mathrm{m}$, was the most abundant and would correspond to cyprids of C. stellatus, which have a CL from approximately 550 to $750 \mu \mathrm{m}$ (O'Riordan et al. 2001). The third modal group, 726 to $900 \mu \mathrm{m}$, is considered to be Balanus perforatus, which have reported CLs from field samples of 611 to $784 \mu \mathrm{m}$ (O'Riordan et al. 2001), but possibly could include cyprids belonging to another species not yet recorded for the area.

\section{Vertical distribution of different cyprid species}

The length frequencies for all cyprids (excluding the low numbers of outliers) are presented in Fig. 6 by depth layers, separated into night and day sampling. The second modal group, considered to be Chthamalus stellatus, includes 4 designated size classes, 526 to 550, 551 to 575,576 to 600 and 601 to $625 \mu \mathrm{m}$, as used by O'Riordan et al. (1999). Previously, Power et al. (1999), in their study using mtDNA-RFLP analysis for separating the 2 Chthamalus species in northern European waters, showed that all individuals in the 526 to $550 \mu \mathrm{m}$ size class were C. montagui. This was further confirmed from CL information by O'Riordan et al. (2001) and by CL and morphological examination by Jenkins (2005). To corroborate this, a correlation analysis was carried out between each depth level, comparing these individual size classes. There was a strong correlation ( $p<0.01$ ) between all but the 526 to $550 \mu \mathrm{m}$ size class. Given the information from previous studies supporting the strong correlation results, it was concluded that this size class was probably an overlapping mixture of species, and because of the uncertainty of identification, it was excluded from further data analysis.

The night and day size-frequency distributions of the cyprids were similar for all layers (Fig. 6), apart from the neuston and 0 to $5 \mathrm{~m}$ layers. These latter layers were statistically different $(p<0.001)$ according to a Kolmogorov-Smirnov test comparing the numbers per cubic metre and length distribution at each depth. In the neuston layer this difference was caused by the presence at night of a large number of Chthamalus stellatus cyprids. In the 0 to $5 \mathrm{~m}$ layer the difference was caused by the presence of higher numbers of individuals belonging to the size class from 726 to $900 \mu \mathrm{m}$, which includes Balanus perforatus, but only at night. They occurred in low numbers, but were most abundant in the first 2 layers, with similar numbers in the neuston layer day and night, although small numbers were found throughout the water column. The first modal group (Pollicipes pollicipes and Chthamalus montagui) were almost totally restricted to the neuston layer, with most present during the day. C. stellatus was the only cyprid species well represented in all layers, at densities of up to 8.7 ind. $\mathrm{m}^{-3}$. In the first 3 layers (surface to $10 \mathrm{~m}$ ), they were more abundant at night, while below $10 \mathrm{~m}$ depth they were always more abundant during the day.

\section{Vertical distribution and migration of Chthamalus stellatus cyprids}

The percentage distribution of the C. stellatus cyprids over the water column, separately plotted for each of the $3 \mathrm{~d}$ of sampling, is given in Fig. 7. There was an obvious diel vertical migration towards the surface at 
night, into the upper $20 \mathrm{~m}$. On Day 1, cyprids started to appear at the surface at $\sim 22: 00 \mathrm{~h}$, and the maximum numbers in this layer were observed between 02:00 and 04:00 h. During this period, the number of cyprids in the 45 to $55 \mathrm{~m}$ depth layer suggested migration up from below the sampling depth. During the daytime,

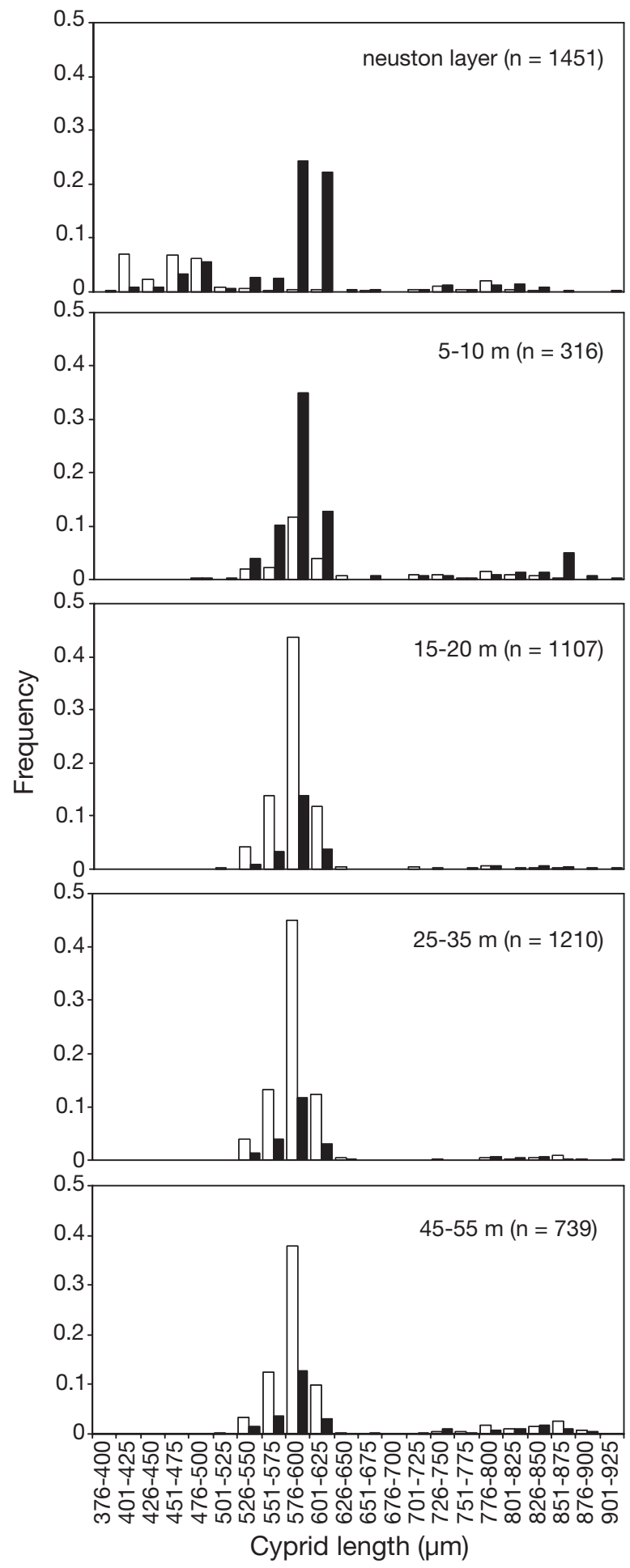

highest numbers were in the 15 to $45 \mathrm{~m}$ depth layer. On Day 2, cyprids were present at the surface layers earlier, at 20:00 h, and reached their highest abundance at 00:00 h. Like Day 1, there appeared to be a migration into the 45 to $55 \mathrm{~m}$ layer from below the sampling depth during the night. During the daytime highest
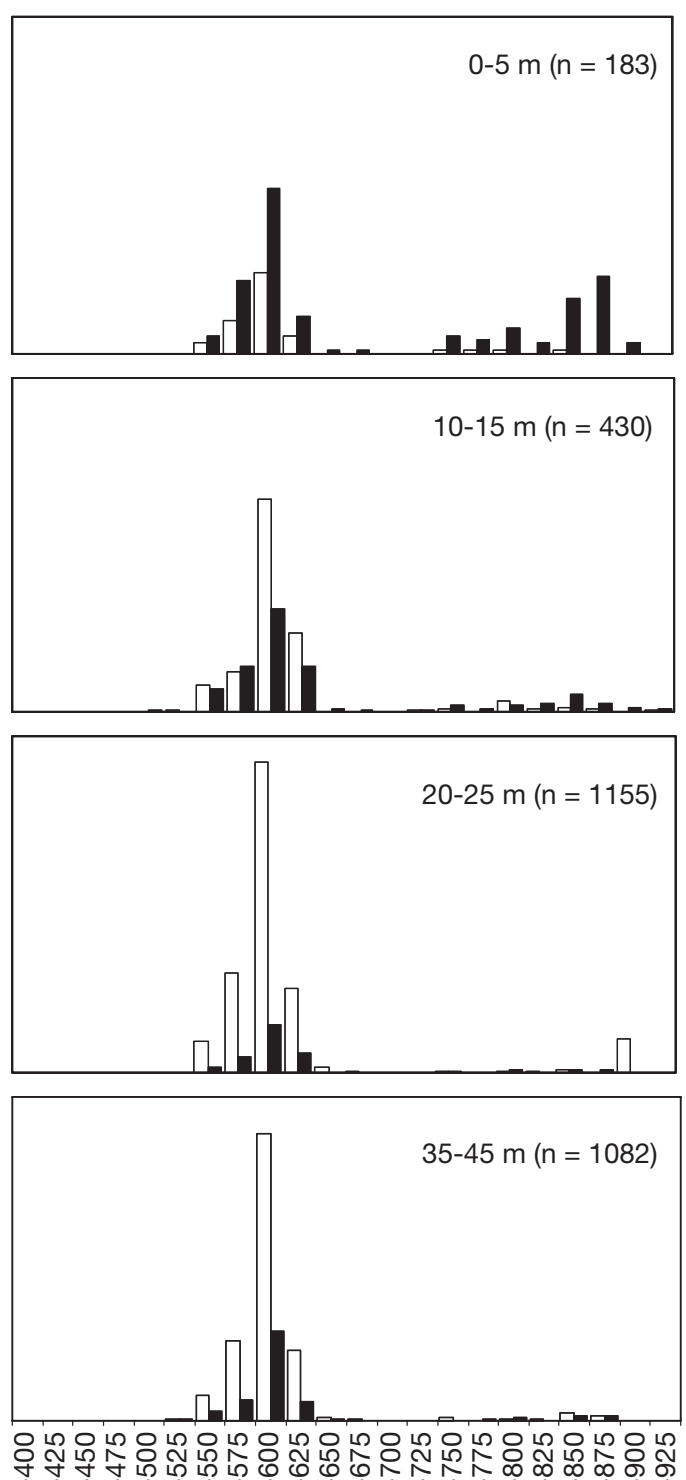

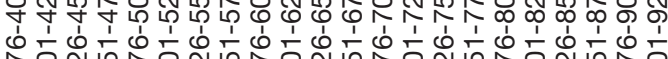

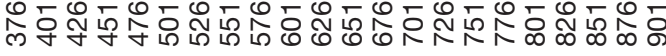
Cyprid length $(\mu \mathrm{m})$

Fig. 6. Size frequency of total cyprids (excluding small numbers $>926 \mu \mathrm{m}$ ) collected at the $69 \mathrm{~h}$ station. Plotting is separate for night and day for the neuston and LHPR samples in each of the depth layers. Open bars are for daytime 


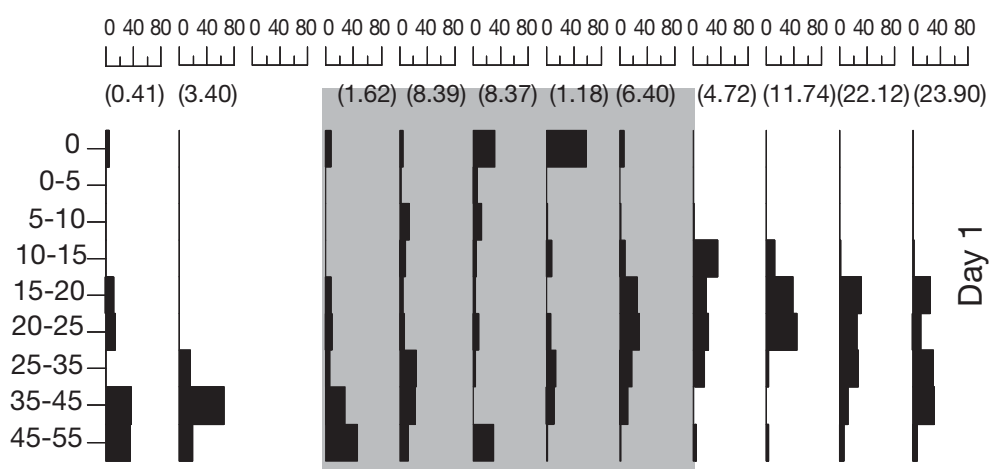

(27.34) (9.69) (10.15) (4.57) (1.56) (1.87) (2.49) (5.78) (12.56)(14.21)(30.12)(30.27)

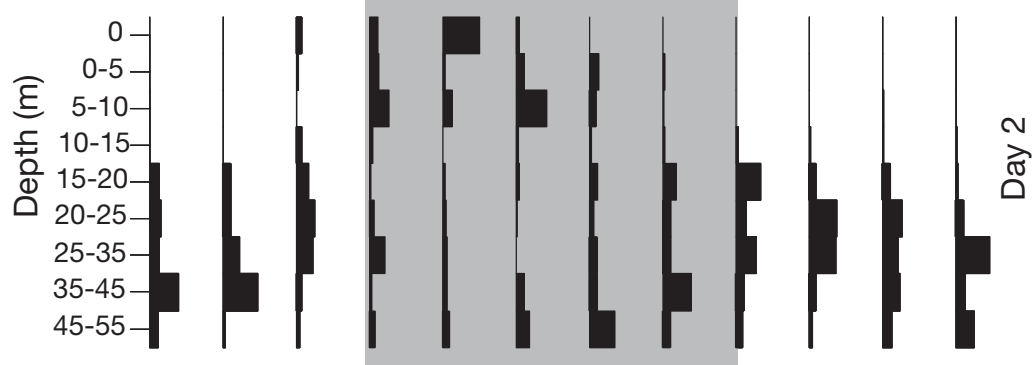

$\begin{array}{llll}(14.83)(9.91)(9.02) & (8.10)(5.38)(10.11)(20.55)(9.70) & (3.58)(11.20)\end{array}$

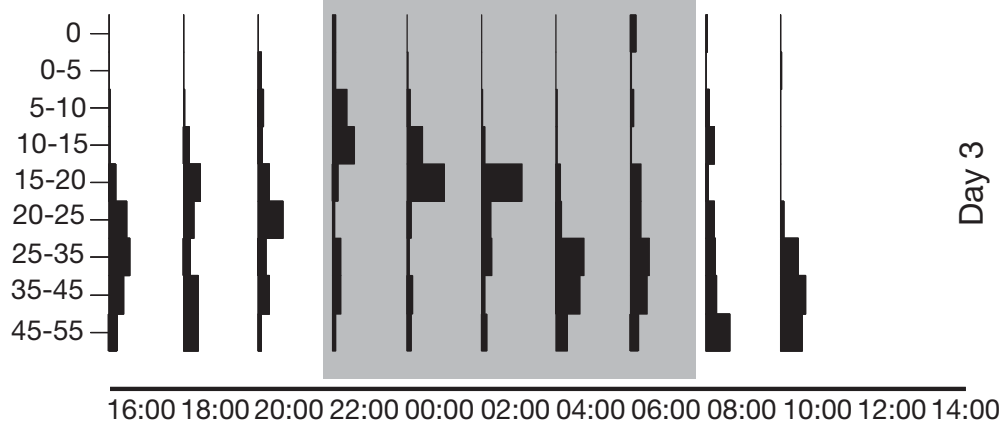

Fig. 7. Chthamalus stellatus. Vertical distribution (as \% of total numbers) of cyprids from the LHPR hauls over the $3 \mathrm{~d}$ of sampling at the $69 \mathrm{~h}$ station.

Numbers in brackets are individuals $\mathrm{m}^{-3}$ for the entire water column at each sampling point. Day 1 20:00 h was not sampled numbers were between 20 and $45 \mathrm{~m}$, slightly deeper than observed in Day 1. On Day 3, cyprids only started arriving at the surface at 22:00 h, and in low numbers.

In order to verify if the vertical migrations had a regular periodicity, an autocorrelation analysis for the Chthamalus stellatus size group (551 to 575, 576 to 600 and 601 to $625 \mu \mathrm{m}$ size classes) was performed using R software. Both positive (daytime) and negative (night-time) values showed a very approximate $20 \mathrm{~h}$ lag period (Fig. 8). This confirmed that the cyprids were performing a daily vertical migration, being mainly below $20 \mathrm{~m}$ during the day and close to the surface at night.

Besides diel vertical migration, on Day 3, the cyprids maintained an overall much deeper distribution than during the previous two $24 \mathrm{~h}$ periods. To examine whether there could be a relationship between cyprid behaviour and light intensity at the surface, Fig. 9 presents the light diffuse attenuation coefficient for the surface layer and the average depth of the cyprids at the sampling station at each sampling interval. This was calculated following data transformation using the moving averages within the time series analysis. The average depth of the Chthamalus stellatus cyprids increased during the observation period and showed a good correlation $(-0.59$, statistically significant at $\mathrm{p}<0.05)$ with the light attenuation coefficient, which decreased slightly after the first day of sampling.

\section{DISCUSSION}
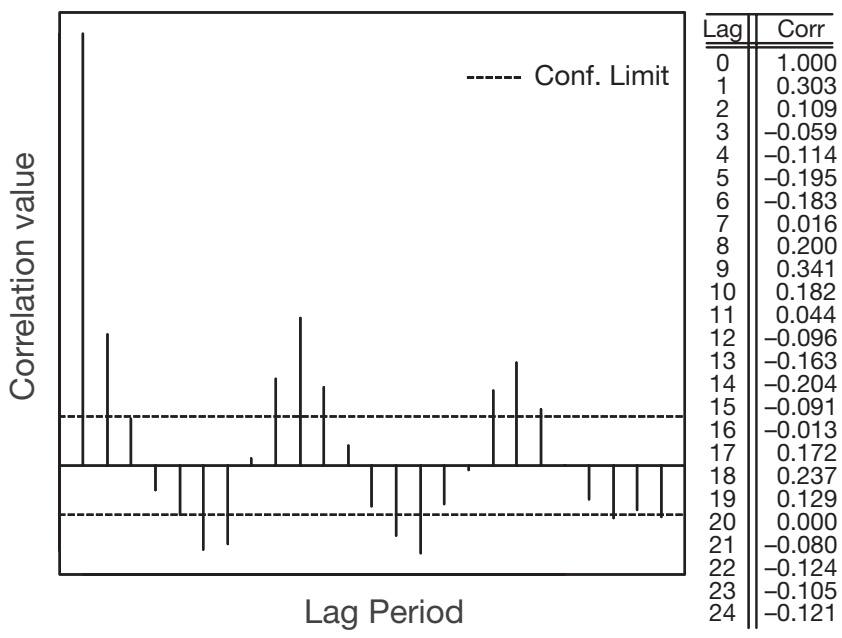

Cyprids sampled during the study were identified based on their carapace length compared to published information (O'Riordan et al. 1999) and the known abundance of different species of adults on the Portuguese coast. This method has been widely used in several ecological studies in Europe (O'Riordan et al. 2004, Cruz et al. 2005, Jenkins 2005). It is improbable that the cyprid size group of 551 to $625 \mu \mathrm{m}$ CL, ascribed in this study to Chthamalus stellatus, would in-

Fig. 8. Chthamalus stellatus. Representation of autocorrelations performed with cyprids for the period of sampling at the $69 \mathrm{~h}$ station. Each lag period corresponds to a $2 \mathrm{~h}$ interval, with indication of correlation values and confidence limit for $\mathrm{p}<0.05$ 


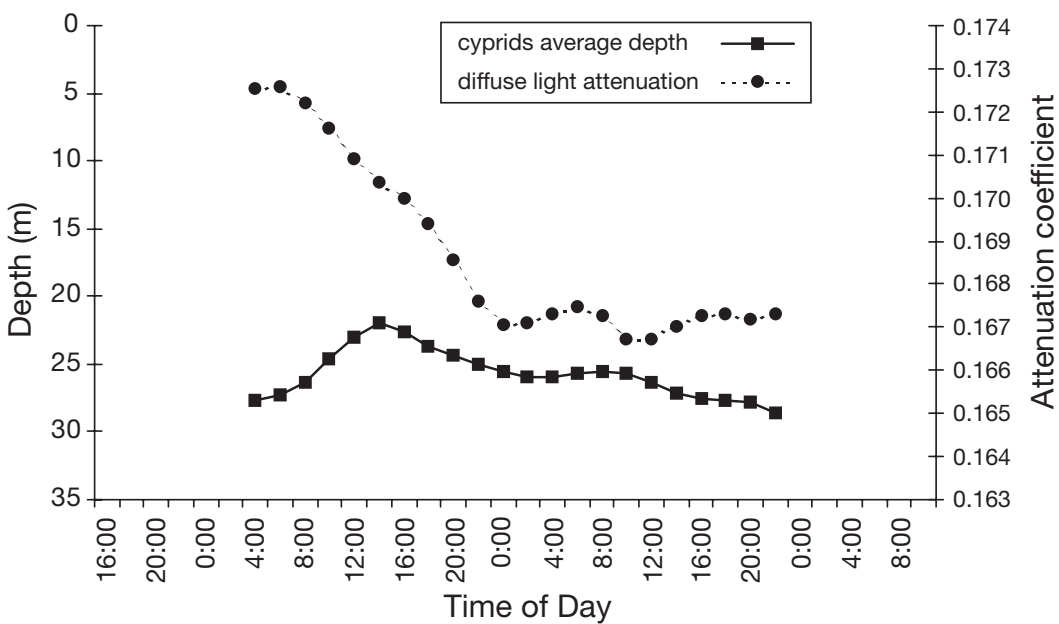

Fig. 9. Chthamalus stellatus. Average depths of cyprids and diffuse light attenuation coefficient $\left(\mathrm{m}^{-1}\right)$, after transformation using the moving average for a 12 lag period (corresponding to $24 \mathrm{~h}$ ), at the $69 \mathrm{~h}$ station

in Portuguese waters, Elminius modestus and Verruca stroemia. However, in a recent census update (O'Riordan \& Ramsay 1999), E. modestus was recorded only from the southern Portuguese coast and $V$. stroemia is considered only a possibility for occurrence in the study area (P. Ré pers. comm.).

The WP-2 net grid sampling showed that cyprids were mainly restricted to an offshore band located between approximately 15 and $30 \mathrm{~km}$ from the Portuguese coast. They were not found $>40 \mathrm{~km}$ from the coast, a maximum dispersal range similar to that found for cyprids of coastal species in other geographical areas (Southward 1962, Ardisson et al. 1990). Neuston net sampling was not carried out on the WP-2 grid, but the surface layer has been shown in other studies (Le Fèvre \& Bourget

clude cyprids of $C$. montagui, as, according to research along European shores (O'Riordan et al. 2001), cyprids of this latter species are always $<500 \mu \mathrm{m}$. Additionally, latitudinal length differences in cyprids are acknowledged, such that those at the northern part of their range tend to be larger than those in the south (e.g. Crisp 1961), so it is unlikely that the C. montagui cyprids could be larger than those from the O'Riordan et al. (2001) study. Moreover, the statistical analysis indicated that the 3 size classes that compose the $C$. stellatus group strongly correlated with each other.

The most abundant cyprids sampled at the fixed station were of Chthamalus stellatus, even though adult populations of $C$. montagui have been reported to dominate the area (Boaventura et al. 2002). Apart from February and March, Chthamalus spp. recruit throughout the year (Range \& Paula 2001), with a peak from July to September, but larval release is not uniform during the reproduction period. In the present study, cyprid abundance was determined from sampling over a $3 \mathrm{~d}$ period in May, so the high abundance of $C$. stellatus relative to $C$. montagui could be because sampling corresponded to a peak of larval release by the $C$. stellatus population. However, there have also been variations reported in the regional abundance of C. montagui adult populations along the Portuguese coast (Range \& Paula 2001), and the north coast has not been as intensively studied as the south, so an area where C. stellatus were more abundant could have influenced the fixed-station observations.

Two other cyprid modal size groups were distinguished in the samples, identified as a Chthamalus montagui/Pollicipes pollicipes mixture and Balanus perforatus. A further 2 cirripede species, with cyprids within the same size range as $C$. stellatus could occur
1991, Rawlinson et al. 2005), and in neuston sampling at the fixed station, to be where high numbers of cyprids can be found. However, the numbers of cyprids observed deeper in the water column, during the fixed station Pro-LHPR sampling, indicated that the WP-2 grid would be an adequate indicator of cyprid horizontal distribution.

There is good evidence that oceanographic processes and fronts can play a major part in the distribution and aggregation patterns of barnacle larvae (Alexander \& Roughgarden 1996, Noda 2004). Ekman transport can carry larvae offshore, where they may accumulate in frontal zones. In a study conducted in the same area and in similar conditions to the present one, i.e. in an upwelling-relaxation phase, after several weeks of upwelling-favourable wind, Peliz et al. (2002) observed the formation of an upwelling front on the middle shelf and a second front on the inner shelf. These conditions could be one of the mechanisms that created the discrete distribution band of cyprids observed in the present study. Indeed, larval transport modelling suggests that intertidal organisms require an offshore front to limit offshore transport, or the population could go extinct (Alexander \& Roughgarden 1996).

The Pro-LHPR and neuston net sampling probably gives the most detailed description of the vertical distribution of coastal cyprids ever carried out offshore. They were mainly in the upper water column, but there were differences between species in the depths occupied, indicating different behaviour. Even in shallow inshore waters, where turbulence would be expected to have a major influence on the vertical distribution of cyprids, there is evidence that at least some species can maintain discrete distribution 
patterns under all conditions of stratification and mixing (Le Fèvre \& Bourget 1991).

The vertical distribution pattern of cyprids in the water column has been suggested to be related to where they prefer to settle in the intertidal zone (Miron et al. 1995), resulting from differences in duration of exposure at particular levels in the intertidal zone. Their proposed settlement patterns would certainly agree with the vertical distribution of Chthamalus montagui and C. stellatus cyprids observed at the fixed station, in relation to the zonation of adults in the Portuguese intertidal zone. Where the 2 species cooccur, the centre of the vertical distribution of adult C. montagui is above that of C. stellatus (Sousa et al. 2000, Range \& Paula 2001), as also noted in other areas (Southward 1976).

Superimposed on the general vertical structuring of the cyprids in the water column, it was obvious that vertical migration between layers was also taking place. The Chthamalus montagui/Pollicipes pollicipes group was most abundant in the neuston layer during the daytime, while the Balanus perforatus group accumulated in the 0 to $5 \mathrm{~m}$ layer at night. Only C. stellatus was present in high enough numbers to allow examination of their detailed vertical distribution, and bulk movements of the population demonstrated that they were performing a vertical migration into, or towards, the surface at night. However, these results do not agree with the sampling carried out by Le Reste (1965), who reported highest abundance of the cyprids of $C$. stellatus in the top $10 \mathrm{~m}$ during the day. However, that study was carried out before C. stellatus and C. montagui were established as separate species (Southward 1976), so they may have been C. montagui.

Vertical migration has been indicated in several cyprid species from studies in coastal waters (Le Fèvre \& Bourget 1991, Garland \& Zimmer 2002, Rawlinson et al. 2005), although most sampling was at one depth only and diel vertical migrations were inferred by changes in abundance at that depth. Similar to the present study, all species did not show the same behaviour. De Wolf (1973) considered that, depending on tidal conditions, cyprids could even settle onto the bottom sediments, and there were certainly indications from the present study that high numbers of Chthamalus stellatus cyprids were at least distributed very close to the bottom.

Chthamalus stellatus cyprids migrated into the surface layers at night during the first $2 \mathrm{~d}$ of sampling at the fixed station, but not in the third night. There is evidence that cyprids respond to changes in light levels (Crisp \& Ritz 1973), so the change in their behaviour may have been because the surface light diffusion attenuation coefficient decreased over the $3 \mathrm{~d}$, indicating more light was penetrating. This was supported by the correlation between light levels and their average depth. Diel vertical migrations cannot be attributed to feeding migrations, as cyprids are a nonfeeding stage, but may be a predator-avoidance mechanism (Pearre 2003), to avoid surface waters when light attenuation is low.

The lens of low salinity water that arrived over the fixed station $12 \mathrm{~h}$ after sampling commenced is unlikely to be the reason the cyprids did not migrate to the surface on the third day, as on the second day they still reached the surface. Garland \& Zimmer (2002) considered that vertical migration behaviour in cyprids was disrupted due to the passage of a downwelled thermocline with a gradient of $\sim 5^{\circ} \mathrm{C}$, while in the present study cyprids passed through a lesser thermocline of $\sim 1.8^{\circ} \mathrm{C}$, a halocline of $\sim 0.2$ and a pycnocline of $0.53 \mathrm{~kg} \mathrm{~m}^{-3}$ without any obvious disruption. Additionally, the passage of 2 internal bores (at $\sim 15 \mathrm{~m}$ depth) was detected at 06:00 and 18:00 h on 20 May (P. B. Oliveira pers. comm.), without any obvious affect on the vertical distribution of the cyprids. However, internal bores are short life structures, and how they would impact the vertical distribution of the zooplankton is not known.

The upwelling that preceded the cruise is characteristic of spring and summer time off the Portuguese coast, the period when cirripede larvae are most abundant. It is well documented that larvae of coastal species can use vertical migration in the vertically sheared flows, which develop as a result of Ekman transport, to retain themselves over the inner shelf close to settlement sites (Alexander \& Roughgarden 1996). However, only the Chthamalus stellatus cyprids showed extensive vertical migration, remaining close to the surface at night for a period of approximately $8 \mathrm{~h}$, most returning to below $20 \mathrm{~m}$ during the day. As they spent a longer time below $20 \mathrm{~m}$, their position from the shore would depend on relative current speeds. In support of the advantage of vertical migration, a modelling study on crab (Carcinus maenas) larvae off western Iberia (Marta-Almeida et al. 2006) showed that there was high dispersal and very low retention if they did not migrate.

The seasonal upwelling-favourable winds off western Iberia have pulses of about 7 to $10 \mathrm{~d}$, interspersed with relaxation periods, during which there are convergence conditions that lead to the onshore movement of the upwelling front and the Western Iberian Buoyant Plume (Ribeiro et al. 2005). Even a proportion of the cyprids that remained in the surface waters may thus have the opportunity to settle.

Chthamalus stellatus and C. montagui, under experimental conditions, took approximately $17 \mathrm{~d}$ to reach the cyprid stage (Burrows et al. 1999), but there is no information about the time taken for their body reserves to become so depleted that they would be un- 
able to metamorphose. As an indication, it is reported that at $10^{\circ} \mathrm{C}$, cyprids of Balanus balanoides can survive for between 2.5 and $4 \mathrm{wk}$ and still metamorphose (Lucas et al. 1979). The timing of oceanographic events, returning cyprids to the coast, may thus determine mortality levels (Alexander \& Roughgarden 1996), but, off the Portuguese coast, these probably fall within the period of cyprid viability.

Acknowledgements. This study was supported by Fundação para a Ciência e Tecnologia (FCT) through the research project 'Pro-Recruit-shelf processes controlling recruitment to littoral populations in an eastern oceanic boundary: using barnacles and crabs as models' (POCTI/1999/BSE/36663). Financial support was allocated by FCT under the Support Community Framework III, Operational Programme Science, Technology and Innovation. Many thanks to J. Pastor and F. Quintela for their counting and measurement of cyprids and to all crew members and technicians on the 2002 ProRecruit survey. In addition, A.d.S. thanks G. Tarling for discussions on the influence of light and the attenuation coefficient. This is a Portuguese contribution to GLOBEC and EUR-OCEANS (EU FP6 No. E511106).

\section{LITERATURE CITED}

Alexander SE, Roughgarden J (1996) Larval transport and population dynamics of intertidal barnacles: a coupled benthic/oceanic model. Ecol Monogr 66:259-275

Ardisson PL, Bourget E, Legendre P (1990) Multivariate approach to study species assemblages at large spatiotemporal scales: the community structure of the epibenthic fauna of the estuary and Gulf of St. Lawrence. Can J Fish Aquat Sci 47:1364-1377

Boaventura D, Ré P, Cancela da Fonseca L, Hawkins SJ (2002) Intertidal rocky shore communities of the continental Portuguese coast: analysis of distribution patterns. PSZN I: Mar Ecol 23:69-90

Broitman BR, Blanchette CA, Gaines SD (2005) Recruitment of intertidal invertebrates and oceanographic variability at Santa Cruz Island, California. Limnol Oceanogr 50: 1473-1479

Burrows MT, Hawkins SJ, Southward AJ (1999) Larval development of the intertidal barnacles Chthamalus stellatus and Chthamalus montagui. J Mar Biol Assoc UK 79:93-101

Crisp DJ (1961) The planktonic stages of the Cirripedia Balanus balanoides (L.) and Balanus balanus (L.) from north temperate waters. Crustac Int J Crustac Res 3:207-221

Crisp DJ, Ritz DA (1973) Responses of cirripede larvae to light. I. Experiments with white light. Mar Biol 23:327-335

Cruz T, Castro JJ, Delany J, McGrath D and 5 others (2005) Tidal rates of settlement of the intertidal barnacles Chthamalus stellatus and Chthamalus montagui in western Europe: the influence of the night/day cycle. J Exp Mar Biol Ecol 318:51-60

De Wolf P (1973) Ecological observations on the mechanisms of dispersal of barnacle larvae during planktonic life and settling. Neth J Sea Res 6:1-129

Fiksen $\varnothing$, Giske J (1995) Vertical distribution and population dynamics of copepods by dynamic optimization. ICES J Mar Sci 52:483-503

Garland ED, Zimmer CA (2002) Hourly variations in planktonic larval concentrations on the inner shelf: emerging patterns and processes. J Mar Res 60:311-325
Jenkins SR (2005) Larval habitat selection, not larval supply, determines settlement patterns and adult distribution in two chthamalid barnacles. J Anim Ecol 74:893-904

Jenkins SR, Åberg P, Cervin G, Coleman RA and 8 others (2001) Population dynamics of the intertidal barnacle Semibalanus balanoides at three European locations: spatial scales of variability. Mar Ecol Prog Ser 217: 207-217

Kugele M, Yule AB (1996) The larval morphology of Pollicipes pollicipes (Gmelin, 1790) (Cirripedia: Lepadomorpha) with notes on cypris settlement. Sci Mar 60:469-480

Le Fèvre J, Bourget E (1991) Neustonic niche for cirripede larvae as a possible adaptation to long-range dispersal. Mar Ecol Prog Ser 74:185-194

Le Reste L (1965) Contribution a l'étude des larves de cirripèdes dans le Golfe de Marseille. Recl Trav Stn Mar Endoume Fac Sci Mars 38:33-121

Lucas MI, Walker G, Crisp DJ (1979) An energy budget for the free-swimming and metamorphosing larvae of Balanus balanoides (Crustacea: Cirripedia). Mar Biol 55:221-229

Marta-Almeida M, Dubert J, Peliz A, Queiroga H (2006) Influence of vertical migration pattern on retention of crab larvae in a seasonal upwelling system. Mar Ecol Prog Ser 307:1-19

Miron G, Boudreau B, Bourget E (1995) Use of larval supply in benthic ecology: testing correlations between larval supply and larval settlement. Mar Ecol Prog Ser 124:301-305

Noda T (2004) Large-scale variability in recruitment of the barnacle Semibalanus cariosus: its cause and effects on the population density and predator. Mar Ecol Prog Ser 278: 241-252

O'Riordan RM, Ramsay NF (1999) The current distribution and abundance of the Australasian barnacle Elminius modestus in Portugal. J Mar Biol Assoc UK 79:937-939

O'Riordan RM, Myers AA, McGrath D, Delany J, Power AM (1999) The sizes at settlement in natural populations of the cyprids of Chthamalus montagui and C. stellatus. J Mar Biol Assoc UK 79:365-366

O'Riordan RM, Delany J, McGrath D, Myers AA and 7 others (2001) Variation in the sizes of chthamalid barnacle postsettlement cyprids on European shores. PSZN I: Mar Ecol $22: 307-322$

O'Riordan RM, Arenas F, Arrontes J, Castro JJ and 13 others (2004) Spatial variation in the recruitment of the intertidal barnacles Chthamalus montagui Southward and Chthamalus stellatus (Poli) (Crustacea: Cirripedia) over and European scale. J Exp Mar Biol Ecol 304:243-264

Pearre S (2003) Eat and run? The hunger/satiation hypothesis in vertical migration: history, evidence and consequences. Biol Rev 78:1-79

Peliz A, Rosa T, Santos AMP, Pissara J (2002) Jets, eddies, and counterflows in the western Iberian upwelling system. J Mar Syst 35:61-77

Pineda J (1999) Circulation and larval distribution in internal tidal bore warm fronts. Limnol Oceanogr 44:1400-1414

Power AM, Piyapattanakorn S, O'Riordan RM, Iyengar A and 5 others (1999) Verification of cyprid size as a tool in the identification of two European species of Chthamalus barnacles using mtDNA-RFLP analysis. Mar Ecol Prog Ser 191:251-256

R Development Core Team (2005) R: a language and environment for statistical computing. R Foundation for Statistical Computing, Vienna. Available at www.R-project.org

Range P, Paula J (2001) Distribution, abundance and recruitment of Chthamalus (Crustacea: Cirripedia) populations along the central coast of Portugal. J Mar Biol Assoc UK 81: 461-468 
Rawlinson KA, Davenport J, Barnes DKA (2005) Temporal variation in diversity and community structure of a semiisolated neuston community. Biol Environ Proc R Ir Acad B 105:107-122

Ribeiro AC, Peliz A, Santos AMP (2005) A study of the response of chlorophyll-a biomass to a winter upwelling event off western Iberia using SeaWiFS and in situ data. J Mar Syst 53:87-107

Santos AMP (2002) News from GLOBEC-PORTUGAL: ProRecruit, a study of shelf processes and coastal/estuarine crustacean recruitment. GLOBEC Int Newsl 8(2):10

Santos AMP, Peliz A, dos Santos A, Ré P (2006) Vertical distribution of the European sardine (Sardina pilchardus) larvae and its implications for their survival. J Plankton Res 28: $1-10$

Sousa EB, Cruz T, Castro JJ (2000) Distribution and abun-

Editorial responsibility: Otto Kinne (Editor-in-Chief), Oldendorf/Luhe, Germany dance of co-occurring chthamalid barnacles Chthamalus montagui and Chthamalus stellatus (Crustacea, Cirripedia) on the southwest coast of Portugal. Hydrobiologia 440: 339-345

Southward AJ (1962) The distribution of some plankton animals in the English Channel and approaches. II. Surveys with the Gulf III high-speed sampler. J Mar Biol Assoc UK 42:275-375

Southward AJ (1976) On the taxonomic status and distribution of Chthamalus stellatus (Cirripedia) in the northeast Atlantic region, with a key to the common intertidal barnacles of Britain. J Mar Biol Assoc UK 56:1007-1028 UNESCO (1968) Zooplankton sampling. UNESCO, Paris

Williams R, Collins NR, Conway DVP (1983) The double LHPR system, a high-speed micro- and macroplankton sampler. Deep-Sea Res 30:331-342

Submitted: December 21, 2005; Accepted: May 24, 2006 Proofs received from author(s): December 6, 2006 